DOI: https://doi.org/10.31933/dijdbm.v2i1

Received: $7^{\text {th }}$ November 2020, Revised: $15^{\text {th }}$ November 2020, Publish: $10^{\text {th }}$ December 2020

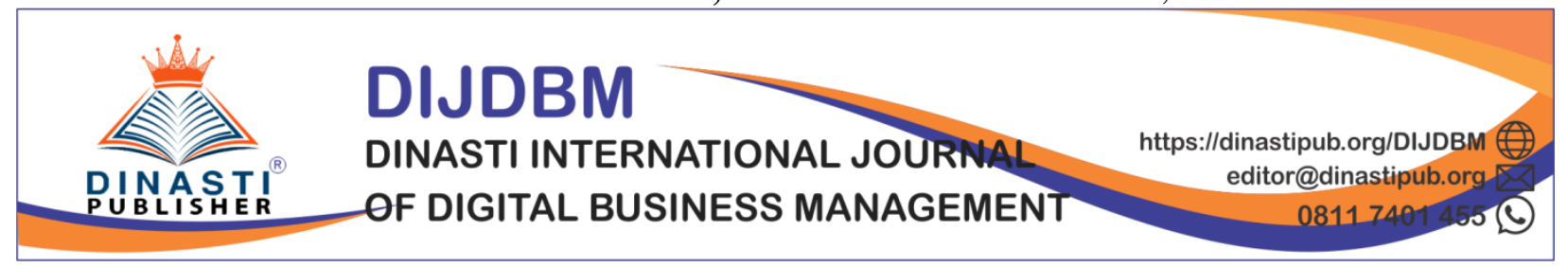

\title{
MADRASAH MANAGEMENT IN IMPROVING TEACHER PROFESSIONALITY (SURVEY AT MIN JAMBI CITY)
}

\author{
Suyanto $^{1)}$, Abd.Rahman ${ }^{2}$, Vivi Yumarni ${ }^{3)}$ \\ ${ }^{1)}$ UIN STS Jambi, Indonesia, suyantojambi2018@gmail.com \\ ${ }^{2)}$ UIN STS Jambi, Indonesia, arahmankemenag71@ gmail.com \\ ${ }^{3}$ UIN STS Jambi, Indonesia, viviyumarni3@gmail.com
}

Corresponding Author: Suyanto ${ }^{1}$

\begin{abstract}
Madrasah management is an activity to empower and coordinate all resources through the planning process, organize, move or implement and supervise to achieve predetermined goals in an effective and efficient manner, including managing teacher professionalism, which can be carried out through education at a higher level according to academic qualifications, Teacher Certification program, Education and Training and training for teachers, Reading Teacher Movement (G2M), KKG organization (Teacher Working Group) and always productive in producing works in the field of education. Characteristics of professional teachers include obeying regulations, maintaining and improving professional organizations, maintaining relationships with peers, guiding students, creating a good atmosphere in the workplace, obeying leaders and love of work.
\end{abstract}

Keywords: Madrasah management and teacher professionalism

\section{INTRODUCTION}

Management issues are an important aspect of madrasah educational institutions. Whether or not a madrasah educational institution is progressing is inseparable from the quality of madrasah management itself. This means that if the management of educational institutions is good, the educational institutions will advance. Conversely, if the management is not good, it will be underdeveloped and even destroyed.

This is especially true in the management of human resources development, both for teaching and education. This is in accordance with the management function according to the experts who have many similarities with each other. According to Henry Fayol and GR Terry, the management function states there are 4 management functions, namely planning - organizing directing - controlling. The object of fostering human resources in madrasas is educators or teachers, how could the madrasah be advanced, if teachers do not have professionalism as educators. Then teachers need to be nurtured and increased in resources so that they can increase their professionalism.

Furthermore, Islam views that human resource development cannot be separated from thinking about humans themselves. Thus Islam means having a very clear, comprehensive and comprehensive concept of resource development. human. According to (Nata, Abuddin, 2001), this concept remains actual and relevant to be applied throughout the ages. Today, national education is facing a crucial issue. The most sensitive issues are related to education quality, education relevance, 
accountability, professionalism, essence, debureaucracy and the attitudes of education policy makers.

Obviously this is still contradicting the Law on National Education System (Sisdiknas) chapter II article 3 which states that the purpose of national education is to develop abilities, shape character and civilization in order to educate the life of the nation, and aim at developing the potential of students to become human beings. have faith and fear in God Almighty, have a noble character, are healthy, knowledgeable, capable, creative, independent, and become democratic and responsible citizens. And in chapter III, article 4, paragraph 6, it is stated that the principle of implementing education is to empower all components of society through participation in the implementation and control of the quality of education services. In general, it cannot be denied that the quality of our education is still very low. This can be clearly seen in the existing education components, both educators, facilities and infrastructure, curriculum, and funds that do not meet standards. For example, many of our educators are not qualified as professional educators because they have not fulfilled their academic demands. Likewise, the existing facilities and infrastructure are still far from appropriate. Our educational curriculum is still trapped in the dichotomy between religious education and general education.

Our education budget is still far from standard. Meanwhile, from outside the education system, the flow of globalization and information also influences the way people perceive education, especially religious education. So the phenomenon that emerges is subordinating religious education, even though Islamic education institutions have a very large role in national education because national education cannot be separated from religious values. Divine values have been used as the basis for the implementation of every learning process in Islamic educational institutions. In addition to encouraging students in a strong religious aspect, Islamic education institutions also study science and technology that are no less compared to general education institutions of an equivalent

(E, Mulyasa, 2004). First, able to empower teachers to carry out the learning process well, smoothly and productively. Second, can complete tasks and jobs in accordance with the predetermined time. Third, being able to establish a harmonious relationship with the community so that they can actively involve them in achieving the goals of school and education. Fourth, successfully applying leadership principles that are appropriate to the maturity level of teachers and other staff in schools and fifthly working with the management team.

Madrasas as Islamic Education Institutions. (Nata, Abuddin, 2004), The word "madrasah" in Arabic means a place or vehicle to experience the learning process. In Indonesian madrasah is called a school which means a building or institution for learning and teaching.

From the above understanding, it is clear that the madrasa is a place or place to study Islamic sciences and other skills that developed during its time. Thus, it can be concluded that the term madrasah originates from Islam itself.

Furthermore, professional teachers are teachers who are able to apply multidimensional relationships. Such teachers are teachers who internally meet administrative, academic, and personality criteria. The requirements for a professional teacher, especially in the perspective of Islamic education. Among these requirements are:

1. Physically and spiritually healthy.

2.Bertaqwa.

3. Knowledgeable.

4. Be fair.

5. Be dignified.

6. Sincerity.

7. Having a goal of being able to plan and carry out an educational evaluation and master the field he is engaged in. 
These seven requirements are important for professional teachers. Broadly speaking, they can be grouped into three categories, namely administrative, academic, and personality requirements. According to (SupRYiningrum, Jamil, 2014) Administrative requirements are requirements that must be possessed by a teacher who wants to become a professional in relation to formal legal requirements. The quality of a person can be seen from the diploma and scientific certificate he has. Academic requirements are requirements that must be possessed by a teacher who wants to become a professional in terms of intellectual capability and quality.

In the Indonesian context, administrative requirements are one of the most important requirements. Academic requirements, namely the requirements that must be possessed by a teacher who wants to become a professional in terms of capabilities and intellectual quality. Academic requirements are also very important requirements for a professional teacher. This requirement greatly determines the success of the educational process it carries out.

The success of education is not only a burden and responsibility of the student as a seeker of knowledge, but it is the teacher who plays the dominant role. Because if the teacher is academically inadequate, then automatically the skills to teach, the ability to master teaching material, as well as evaluate student success are not possessed accurately and correctly. This is clearly very detrimental to the educational process which is not only fatal for a student, but for all students or even all education.

According to (Sagala, Syaiful, 2009) in his book Professional Ability of Teachers and Education Personnel. He wrote that the standards required to be a professional teacher are as follows:

1. Passing down culture in the form of skills, intelligence and empirical experience to his students.

2. Shaping the personality of students in accordance with the basic values of the State.

3. Having a Pancasila spirit.

4. Deliver students to become good citizens.

5. Directing and guiding children so that they have maturity in speaking, act and behave.

6. Functioning themselves as a liaison between the school and the community environment, either Public or private schools.

7. Must be able to initiate and enforce discipline both for himself and for students and other people.

8. To function as a preferred administrator and manager at the same time.

9. Doing his job perfectly as a professional mandate.

10Teachers are given the greatest responsibility in terms of planning and implementing the curriculum and evaluating its success

11. Guide children to learn to understand and solve problems faced by their students.

12.Teachers must be able to stimulate students to have high enthusiasm and strong passion in forming study groups, developing extra-curricular activities in order to explore experiences.

According to (Suprihatiningrum, Jamil, 2014). Teachers are professional educators with the main task of educating, teaching, guiding, directing, training, assessing, and evaluating students in early childhood education, formal education, primary and secondary education. People called teachers are people who have the ability to design learning programs, and are able to organize and manage the class so that students can learn and in the end can reach maturity level as the ultimate goal of the educational process.

The various characteristics of professional teachers according to (Abdul Aziz, Hamka, 2012) are as follows:

1. Obeying laws and regulations 
In the Indonesian teacher code of ethics item nine states that "teachers implement all government policies in the field of education". The education policy in our country is held by the government. In the framework of education development in Indonesia, the government through the Ministry of National Education issues regulations and provisions which are policies that will be implemented by its apparatus. One of the elements of the state apparatus is the teacher. Therefore, teachers absolutely need to know the policies of the government in particular. in the field of education so that they can carry out these policies.

2. Maintain and Improve Professional Organizations

Teachers jointly maintain and improve the quality of teacher organizations as a means of struggle and dedication. The Indonesian Teachers Association (PGRI) is one of the teacher professional organizations. PGRI as a profession requires guidance to be more efficient and effective as a means of business to carry out the mission and strengthen the profession teacher. The success of this Sunnah business depends on the awareness of its members, the sense of responsibility and obligation of its members.

In the sixth item of the teacher code of ethics it is said that teachers personally and jointly develop, improve the quality and dignity of their profession. This basis is very firm obliging all members of the teaching profession to always improve the quality and dignity of the teacher profession itself.

3. Maintaining Relationships With Peers.

In point seven of the teacher's code of ethics, it is stated that teachers maintain professional relationships, family spirit, and social solidarity, this means that teachers should create and maintain relationships with fellow teachers in their work environment, also teachers should create and maintain a family spirit and social solidarity in an outside environment. it works.

Relationships between members of the profession can be seen from two aspects, namely formal relationships and kinship relationships. Formal relationships are relationships that need to be done in order to carry out official duties. While kinship is a sibling relationship that needs to be done both in the work environment and in the overall relationship in order to support their achievement the success of members of the profession for example as nation educators.

4. Guiding Students

In the teacher's code of ethics it is clearly written that the dedicated teacher guides students to whole Indonesian people who have the spirit of Pancasila. The characteristics that students really like are:

a. Teacher democracy gives freedom to students, provides opportunities to participate in various activities, and is not authoritarian.

b. Cooperative cooperation, tolerance, and based on high kinship.

c. Kindness, that is, likes to give and sacrifice for their students.

d. Patience is a teacher who is able to hold back.

e. Fair, which is not discriminating against students in all things.

f. Be consistent, that is, always act according to what he says.

g. Be open willing to accept criticism, suggestions and admit shortcomings.

h. Helpful.

i. Friendly.

j. Loves humor.

k. Have various interests.

1. Complete lesson material.

m. Care and concern for students.

5. Creating a good atmosphere at work. 
A good atmosphere in the workplace will increase productivity. This is well recognized by every teacher, and teachers are obliged to create a good atmosphere in the environment to create a conducive atmosphere.

6. Obey the leader

From the teacher organization, there are leadership strata ranging from the management of regional branches to the central government. Likewise with the education office. Thus a teacher must be obedient to his leader by implementing policies by listening to the directions given by policy makers.

7. Love of Work

People who already have a teaching profession will be successful if they love their work. This means that he does whatever it takes to make his career work well, including his duties to serve well to those who need his help. A professional worker, especially a teacher can be distinguished from a technician, because in addition to mastering certain techniques and work procedures, a professional worker is also characterized by Informed responsiveness to the social implications of his work object. This means that a professional worker or teacher must have a perception philosophical and wise responsiveness who is more stable in addressing and carrying out his work. In a work of a professional nature, techniques and procedures that are based on an intellectual basis are used, which must be deliberately studied and can be directly used for the benefit of others. In essence, a professional worker is a person who performs service or dedication based on professional abilities and a stable life standard. Professional jobs can also be said to be jobs that are prepared through a process of education and training.

\section{LITERATUREREVIEW}

\section{Management Concept}

According to (Fajriansyah, M, Rizki, 2019), the term management in English comes from the verb to manage which means to manage, organize, implement, and manage, while in Latin, the term management comes from the word manui and means the hand in control horse so that the horse can be directed to achieve a good goal. So in terms of management can be defined as something that controls or is in control.

Definition of management. Management does not have an absolute definition that is universally accepted. Management is defined by experts according to their point of view and in accordance with their respective knowledge. The following is the understanding according to experts:

a. (Luther Gullick, 1992), states that management includes the processes of planning, organizing, staffing, derecting, operating, reporting, budgeting and supervising (POSDCORBS).

b. (Longest, 1978), states that management is a process involving interpersoanal relationships and technology that will be used to achieve all or at least part of the organizational goals by using existing human resources and other available resources and technology.

c. Mary Parker Tollet (Hellriegel and Stacum, 1992), states that management is the art of completing work through other people.

d. Wren (in Modern Health Administration, 1974), states that management is an art and science or an art that has a scientific landscape where management science itself can be learned through formal education and the artistic aspects of management can be obtained from experience, trial and error or from other people's experiences.

e. From some of the above meanings, it can be concluded that management is an activity to organize other people to achieve goals or complete work.

The teacher standards are described in the Government Regulation of the Republic of Indonesia (2005) as follows: Educators must have academic qualifications and competencies as learning agents, be physically and mentally healthy, and have the ability to realize the goals of national education. 
1. Academic qualification as referred to in subsection (1) is the minimum level of education that must be fulfilled by an educator as evidenced by a relevant diploma and or certificate of expertise in accordance with the provisions of the applicable laws.

2. Competence as a learning agent at the primary and secondary education and early childhood education levels include:

a. Pedagogic competence,

According to (Ramayulis, 2002), pedagogical competence is the competence or ability of teachers in the management of student learning, pedagogical competence includes understanding of students, designing and implementing learning, learning evaluation, and developing students to actualize their various potentials (Talib,Syamsul Bachri. 2013), These competencies include: a. Understand the foundation of education b. Able to plan, implement, evaluate the learning process c. Understand, develop the potential of students d. The ability to carry out the supporting elements, for example understanding school administration, guidance, and counseling e. The ability to carry out research and scientific thinking to improve performance as an educator

b. Personality competence, According to (Thalib, Syamsul Bachri, 2013), personality competence is a personal ability that reflects a solid, stable, mature and authoritative personality, is a role model for students, and has noble character. In detail, the supkompetensi can be described as follows: a. Steady and stable personality supkompetency has essential indicators: acting in accordance with legal norms, acting in accordance with social norms, being proud to be a teacher, and having consistency in acting in accordance with norms. b. Adult personality sub-competencies have essential indicators: displaying independence in acting as educators and having a work ethic as a teacher. c. The subcompetence of a wise personality has essential indicators: displaying actions that are based on the benefit of students, schools, and society and showing openness in thinking and acting. d. An authoritative personality subcompetence has an essential indicator: having a behavior that has a positive effect on students and having respected behavior. e. Personality sub-competencies who are noble and can be role models have essential indicators: acting according to religious norms (faith and piety, being honest, sincere, helpful), and having exemplary behavior.

c. Professional competence.

Professional competence is the mastery of learning material in a broad and deep manner, which includes mastery of the subject curriculum material in schools and the scientific substance that covers the material, as well as mastery of the structure and scientific methodology. Each of these sub-competencies has the following essential indicators: a. Sub-competence in mastering science related to the field of study has essential indicators: understanding the teaching materials in the school curriculum; understand the structure, concepts and scientific methods that are shading or coherent with the teaching material; understand the conceptual relationship between related subjects; and apply scientific concepts in everyday life. b. Sub-competence in mastering scientific structures and methods has an essential indicator: it has research steps and critical studies to deepen the knowledge / material of the field of study.

d. Social competence. Social competence Social competence is the ability of a teacher to communicate effectively with students, fellow educators, education staff, parents / guardians of students, and the surrounding community. This competency has subcompetencies with the following essential indicators: a. Able to communicate and mingle effectively with students, this subcompetence has an essential indicator: communicate effectively with students. b. Able to communicate and mingle effectively with fellow educators and education personnel. c. Able to communicate and get along effectively with 
parents / guardians of students and the surrounding community. It should be explained that in practice the four competences (personality, pedagogical, professional, and social) constitute a complete whole. This sorting is solely for the convenience of understanding it. This refers to the view (Syamsul Bachri Thalib, 2013), which states that as a competent teacher has (a) an understanding of the characteristics of students, (b) mastery of the field of study, both from a scientific and academic perspective, (c) the ability to organize learning which educates, and (d) the willingness and ability to develop professionalism and personality in a sustainable manner.

There are many types of madrasah management related to improving teacher professionalism, including: Regulation of the Minister of Religion of the Republic of Indonesia Number 16 of 2010 concerning Management of Religious Education in Schools. Chapter VI Educators and Education Personnel Part One Religious Education Teachers Article 13 Religious Education Teachers have at least a Strata 1 / Diploma IV academic qualification, from a religious education study program and / or a religious study program from an accredited tertiary institution and hold a religious education teacher professional certificate. Article 14 (1) The provision of religious education teachers in schools run by the Government is carried out by the Minister. (2) The provision of religious education teachers in schools run by the Regional Government is carried out by the Minister and / or the Regional Government.

2. Teacher professionalism

According to (Danim, Sudarman, 2002), Etymologically, the profession comes from professional English or Latin Profecus, which means acknowledging, acknowledging being able to, or being expert, in carrying out certain jobs. Also according to (Damin, Sudarman, 2002), in terminology, a profession can be defined as a job that requires higher education for the perpetrator which emphasizes mental work, not manual work. The mental faculties referred to here are the requirements of theoretical knowledge as an instrument for performing practical actions.

In (Big Indonesian Dictionary, 2001) professional is defined as "something that requires special skills to run it". In other words, professional is a set of skills that are required to do a job that is done efficiently and effectively with a high level of expertise in order to achieve maximum job goals. The term professional comes from the word profession. In the dictionary "The advanced Learner's Dictionary of Current English, which is written (A.S. Hornby, et al. 1973) states that" profession is accuption, esp. one requiring advanced educational and special training ". This means a position that requires a higher education and special training. A position will determine the activities of executing the task. It means that it is not the position that holds the title of professional, but the expertise in carrying out the work. Based on that definition in above, (Arikunto, Suharsimi.1883) provides a professional definition as follows. First, in professional work, techniques and procedures are needed that are based on intellectual foundations learned from an institution (whether formal or not), then applied in society for problem solving. Second, a professional can be distinguished from a technician in terms of having a strong philosophy to be responsible for his work, and being stable in addressing and carrying out his work. Third, a person who works by profession requires scientific techniques and procedures and has a high dedication in dealing with the field. work based on the attitude of an expert. According to Dedi Supriadi, the use of the term professional is meant to refer to two things, namely first, the appearance of a person in accordance with the demands that should be. For example, "he is very professional". Second, a meaning that refers to the person. "He is a professional", such as a doctor, engineer and so on.

There are many ways to fulfill juridical demands in improving teacher professionalism, including the following: 
1. Taking education at a higher level according to academic qualifications

This is based on the Lecturer Teacher Law that teachers to gain professional competence must go through professional education and teachers are also required to have minimum academic qualifications of S-1 or D4. Especially at this time, the development of the world of education and the education system is increasing. the level of education is expected that teachers can increase their knowledge and obtain new information in education so that teachers know the development of education science.

2. Through the Teacher Certification Program

One of the efforts to improve teacher professionalism is through certification, in which certification is reflected in the existence of a fit and proper test that a person must undergo against the criteria that are ideally set. With the existence of certification, it will spur the spirit of teachers to improve themselves, improve the quality of knowledge, and professionalism in the world of education.

3. Providing training and training for teachers

Education and training and training are one of the coaching techniques to increase teacher insight / knowledge. Training and training activities need to be carried out by teachers followed by follow-up efforts to apply the results of training and training.

4. Reading Teacher Movement (G2M)

5. Teachers should have an awareness of the importance of reading to develop insight and knowledge.

It is not funny if the teacher tells the students to be diligent in reading while the teacher is reluctant to read. We as teachers must be more knowledgeable than students. For this reason, the Reading Teacher Movement needs to be promoted. In this case the teacher can take advantage of available books or mass media. in libraries, schools or bookstores, or you can also access the internet about matters related to his specialty or general knowledge that can add to his insight.

6. Through the KKG organization (Teacher Working Group)

One of the places or places that can be used to foster and improve the professionalism of madrasah teachers is through the Teacher Working Group (KKG). The Teacher Working Group (KKG) is a forum for teacher-teacher cooperation and a place to discuss issues related to ability professional, namely in terms of planning, implementing and assessing student progress.

7. Always productive in producing works in the field of education.

Teachers should have the awareness to write more, especially on educational and teaching issues. This is one of the methods to improve the teacher's ability to express concepts and ideas in written form. Every teacher must be aware and willing to train himself if he / she really wants to cultivate his own creativity through writing (for example; Classroom Action Research, teaching materials, articles, and so on).

(Hamalik, Oemar, 1994) in his book Teaching and Learning Process, professional teachers must have requirements, which include;

a. Have talent as a teacher.

b. Having skills as a teacher.

c. Have good and integrated skills.

d. Have a healthy mentality.

e. Be in good health.

f. Have extensive experience and knowledge.

\section{RESEARCH METHODS}

Researchers used a qualitative-naturalistic approach. Through this qualitative approach, it is hoped that a picture of the quality, social reality and perceptions of the research objectives will be lifted without being contaminated by formal measurements. The naturalistic approach demands data 
collection in a natural setting. With this concept, researchers strive so that the presence of the researcher does not change the situation or behavior of the person being studied. The methods of collecting data in the field are observation, interview and documentation.

\section{FINDINGS AND DISCUSSION}

Based on the aforementioned regulations, it is very clear that Religion teachers must have a Strata 1 / Diploma IV academic qualification from an accredited Higher Education Religion study program and have an educator certificate.

documents at Madrasah Ibtidaiayah Negeri (MIN) Jambi City as follows:

Table 1.Documentation Data on Education Certificate Qualification

\begin{tabular}{|l|l|l|c|c|c|c|}
\hline \multirow{2}{*}{ No } & Type & Total & \multicolumn{3}{|l|}{ Qualifying Diplomas } & \multirow{2}{*}{ Information } \\
\cline { 3 - 6 } & & & Already S1 & Already S2 & Already S2 & \\
\hline 1 & Mapel Teachers & 10 & 9 & - & 2 & \\
\hline 2 & Class teachers & 24 & 21 & 8 & 3 & \\
\hline
\end{tabular}

In addition, etymologically the word qualification is adopted from English qualification which means training, test, diploma, etc. that qualifies a person (Manser, 1995). Qualification means training, tests, diplomas and others that qualify a person. (Depdikbud, 1996) qualification is "special education to obtain a skill required to do something or occupy a certain position" Qualification means the requirements that must be met in relation to ability. needed to carry out a job. Qualification can show the credibility of a person in carrying out his job.

(Miarso, 2008 stated that a qualified teacher is a teacher who meets educator standards, masters subject matter / content according to content standards, and lives and implements the learning process in accordance with the learning process standards. Miarso defines qualifications as abilities or competencies that a person must possess. teachers in carrying out their duties.

From several definitions of qualifications above, the term qualification is broadly understood from two different points of view. First, qualification as the level of education that must be taken by a person to gain authority and legitimacy in carrying out his profession, while the second view defines qualification as an ability or ability. competencies that must be possessed or mastered by a person so that they can carry out their work in a quality manner. However, in fact there is a common thread from both points of view, namely the necessity of having the capacity to be fulfilled to carry out a profession or job.

The ideal teacher according to verses 1-5 surah al-'Alaq is;

First, a teacher must have broad knowledge and insight. Because, how is it possible for us to achieve maximum results in educating and teaching, if the quality and resources of the teachers are minimal and limited. That is why it is Allah who mentions His Essence as a human Teacher who teaches what he does not know. As in Surah al-'Alaq verse 5

"He taught man what he did not know."

Therefore, ideally a teacher is someone who is required to always be able to create something new, both in terms of learning materials and methods and methods, so that teaching is not static and always moves in the direction of progress. Of course, teachers in this case are required to always add to their knowledge, which can be done in various ways, such as formal education, training, reading a lot, listening to discussions and so on. Indeed, that is the message of Allah to every human being who is in the world of education, so that they become Rababni People. The Word of Allah SWT. surah 'Ali Imran verse 3: 79 
"It is not natural for a human being that Allah gave him the Bible, wisdom and prophecy, then he said to humans:" You should be my worshipers, not worshipers of Allah. " But (he said): "Be rabbani people, because you always teach the Bible and because you keep studying it."

Second, a teacher must be able to encourage and motivate all his students to always be active and creative. An ideal teacher is not to force his students to learn, but rather to provide motivation and stimulation. That is why, the word iqra '(read) is repeated twice in surah al-'Alaq verses 1 and 3. "Read by (mentioning) the name of your Lord Who created (1). He has created man from a clot of blood (2) Read it, and your Lord is the Most Gracious (3). "

And on the second reading command, Allah promises His start to be poured out for those who actively read. That is a form of motivation for a teacher to his students, so that they are active and creative.

Third, an ideal teacher is not only able to instruct and invite students to actively read, but also be able to balance it with writing skills. That is what is mentioned in Surah al-'Alaq verse 4

"Who teaches (humans) by means of kalam."

Knowledge that has been mastered, if not written down, will usually easily disappear and disappear from memory. Like an animal, if it is left untied, of course it will easily go away and leave its owner. That is one of the characteristics of science, which also demands bonding. And the bond of knowledge is when it is written on sheets of paper.

That is the attitude of a teacher in teaching, let them know the attitude, character and personality of their students well. So that teachers can provide the correct materials and methods in carrying out the learning and teaching process. In a formal juridical manner, (Law on teachers and lecturers, 2005) mandates that the teaching profession is a special field of work carried out based on the following principles: having academic qualifications, educational background in accordance with the field of work and has the competence needed to carry out that task field. Article 9 states that the qualifications referred to are obtained through higher education at the S1 or D4 level. Teacher academic qualifications reflect the abilities required for teachers to carry out their duties as educators at the level, type, and education unit or subject they take. Furthermore, Article 20 letter b states that teachers are obliged to continuously improve and develop academic qualifications and competencies in line with the development of science, technology and arts.

Teachers who meet educator standards are teachers who have academic qualifications in accordance with regulations, namely undergraduate (S1) or diploma four (D4) programs. According to Ningrum, the academic qualification of an educator or teacher is the minimum level of education that must be fulfilled by an educator as evidenced by a relevant diploma or certificate of expertise in accordance with the provisions of the applicable laws.

Academic qualifications are not only based on education level, but the relevance of the teacher's educational background to the subjects being taught. This qualification can show the professional competence of teachers, especially those related to mastery of materials, methods, media and learning resources as well as the ability to create patterns of educational interactions in the learning process.

Furthermore, the relationship with teacher professionalism, according to the results of the researchers' observations when looking directly at the documents at the Jambi City Public Madrasah Ibtidaiyah (MIN) regarding the ownership of teacher certificates as follows:

Table 2

Educator certificate documentation data as follows

\begin{tabular}{|c|c|c|r|}
\hline No & Type & Educator Certificate Ownership & Information \\
\hline
\end{tabular}

Available Online: https://dinastipub.org/DIJDBM 


\begin{tabular}{|c|c|c|c|c|}
\hline & & Have & Not yet & \\
\hline 1 & Subject teacher & 7 & 3 & New Teacers \\
\hline 2 & Teacher class & 23 & 1 & Still in College \\
\hline
\end{tabular}

The results of the aforementioned document are reinforced by the results of an interview with one of the education staff with the initials $\mathrm{NH}$, saying that it is true that the class teacher with the initials $\mathrm{NH}$ does not yet have an educator certificate and an interview with the teacher with the initials IS said that it is true that I am a teacher of fiqh subjects and a friend. I, with the initials MR, do not have this educator certificate because I was just appointed as a civil servant.

A similar opinion was also expressed by another Arabic teacher with the initials AH that it is true that the teachers at Madrasah Ibtidaiyah Negeri (MIN) Jambi City are all certified except for me as an Arabic teacher.

From the results of observations, interviews, then by looking at the documents in Madrasah Ibtidaiyah Negeri (MIN) Jambi City, the results remain the same. Besides observing the ownership of educators' certificates, the researchers also observed training participation. Teacher Working Groups and work in education, as follows:

Table 3

Training documentation data, KKG and scientific works of teachers

\begin{tabular}{|c|c|c|c|c|c|c|c|c|c|}
\hline \multirow{2}{*}{ No } & \multirow{2}{*}{ Type } & \multirow{2}{*}{ Total } & \multicolumn{6}{|c|}{ Participation in Activities } & \multirow{2}{*}{ Inf } \\
\cline { 4 - 9 } & & & \multicolumn{2}{|c|}{ Work } & \multicolumn{2}{|c|}{ KKG } & Training & \\
\cline { 4 - 9 } & & Have & Not yet & Have & Not yet & Never & $\begin{array}{c}\text { Not } \\
\text { Never }\end{array}$ & \\
\hline 1 & Subject teacher & 10 & 8 & 2 & 8 & 2 & 8 & 2 & \\
\hline 2 & Teacher class & 24 & 24 & - & 24 & - & 24 & - & \\
\hline
\end{tabular}

The results of the document research were strengthened by an interview with the administration department with the initials NA, saying that in fact, in training activities, both the Education and Training Center held by the Education and Training Center, as well as the Ministry of Religion of Jambi City, the average teacher of Madrasah Ibtidaiayah Negeri (MIN) Jambi City participated Except for two people, because these two people have just been appointed as civil servants. Likewise, the activities of the Teachers Working Group (KKG) for the average Madrasah Ibtidaiayah Negeri (MIN) Madrasah Jambi City teacher have participated in all of them, it's just that there is a problem with a little relationship between times which often collides between Teacher Working Group (KKG) time with learning time. Likewise in terms of producing work in education, the average public Madrasah Ibtidaiayah (MIN) Madrasah Jambi City teacher has produced educational work, it's just that the interest is only for advancing in rank, apart from that it is very rare.

The interview was strengthened with another administrative employee with the initials DS. From the results of the documentation, the researcher strengthened it with interviews about participation in the Education and Training, Teacher Working Group (KKG) and the results of the work, the results remained the same as the results of the documentation above.

\section{CONCLUSION AND RECOMMENDATION}

Madrasah management is the spirit of educational institutions, without good management the educational institutions will not run perfectly, both in the areas of planning, organizing and monitoring. In the field of organizing, planning and monitoring in order to improve teacher professionalism, it can be pursued through education at a higher level according to academic qualifications, Teacher Certification programs, Education and Training for teachers, Reading 
Teacher Movement (G2M), KKG organization (Teacher Working Group) and always productive in producing works in the field of education.

As for the characteristics of a professional teacher, namely: Having talent as a teacher, having expertise as a teacher, having good and integrated skills, having a healthy mentality, being in good health, having extensive experience and knowledge, having the spirit of Pancasila, while according to Kunandar, a teacher who is The professional has skills based on deep scientific concepts and theories, has expertise in a particular field in accordance with his / her professional field, has an adequate level of education, is sensitive to the societal impact of the work he carries out and has developmental thoughts in line with the dynamics of life.

\section{BIBLIOGRAPHY}

Nata, Abuddin, 2001. The History of Islamic Education in the Classical and Middle Periods.

Jakarta: PT. Raja Grafindo Persada.

Arikunto, Suharsimi, 1883. Humane Teaching Management, Jakarta: Rineka Cipta.

Abdul Aziz, Hamka Abdul, 2012 Character Professional Teacher, Jakarta: Al Mawardi.

Arikunto, Suharsimi and Yuliana, Lia, 2008. Education Management, Yogyakarta Adtya

Yogyakarta media.

Ministry of Education and Culture. 1996. Special Methods for Development of Educational and Cultural Capabilities, Directorate General of Primary and Secondary Education, Directorate of Primary Education, Section of the Project for Improving Kindergarten Quality

Danim, Sudarwan, 2002, Educational Innovation in Efforts to Improve Professionalism of Educational Personnel, Bandung: Pustaka Setia.

E, Mulyasa, 2004. Competency-Based Curriculum, Concept, Characteristics, Implementation and Innovation, Bandung: PT. Rosda Karya Youth.

Isniati and Fajriansyah, M, Rizki, 2019, Strategic Management, Concepts \& Theory Digest, Yogyakarta, Andi.

Horn et al, 1973. The advanced Learner's Dictionary of Current English, Great Britain: oxford University.

Hamalik, Oemar, 2006. Teaching and learning process. Jakarta: PT. Earth Literacy.

Kunandar, 2007. Professional Teacher: Implementation of Education Unit Level Curriculum and Success in Teacher Certification, Raja Grafindo Persada, Jakarta.

Kunandar, 2007. Professional Teacher: Implementation of Education Unit Level Curriculum and Success in Teacher Certification, Raja Grafindo Persada, Jakarta.

Miarso Y. 2008. Improving Teacher Qualifications in the Perspective of Educational Technology.Journal of Sower Education 7 (10).

Republic of Indonesia Government Regulation, 2005. Number 19 concerning SNP. Law, 2003 National Education System No. 20.

Law Number 14 of 2005 concerning Teachers and Lecturers

Ramayulis, 2002, "The Science of Islamic Education", Jakarta: Kalam Mulia, 2002,

Suprihatiningrum, Jamil, 2014. Professional Teacher., Jogjakarta: Ar Ruzz.

Sagala, Syaiful, 2009. Professional Teachers and Education Personnel. Bandung: Ikapi

Thalib, Syamsul Bachri, 2013. "Educational Psychology Based on Applicative Empirical Analysis", Jakarta: Kencana.

Language Center of the Ministry of National 